\title{
HUBUNGAN ANTARA MOTIVASI BELAJAR DAN HASIL BELAJAR SISWA SDN EMMY SAELAN MAKASSAR
}

\section{RELATIONSHIP BETWEEN LEARNING MOTIVATION TO LEARNING RESULT MATHEMATICS STUDENTS SDN EMMY SAELAN MAKASSAR}

\author{
Nur Yuliany \\ UIN Alauddin Makassar \\ J1. H.M. Yasin Limpo No.36 Samata-Gowa \\ Email: nur.yuliany@uin-alauddin.ac.id
}

\begin{abstract}
Abstrak
Tujuan penelitian ini adalah untuk mengetahui bagaimana pengaruh motivasi belajar terhadap hasil belajar matematika siswa SDN Emmy Saelan Makassar. Penelitian ini merupakan penelitian eksperimen dengan jenis penelitian Quasi Experimental dengan desain penelitian yang digunakan dalam penelitian ini adalah Non Equivalent Control Grup design. Teknik pengambilan sampel yang digunakan adalah random sampling. Instrumen penelitian yang digunakan dalam pengumpulan data adalah angket dan dokumentasi. Teknik analisis data yang digunakan adalah analisis deskriptif dan analisis statistik nonparametrik. Hasil dari analisis deskriptif untuk motivasi belajar siswa dalam kategori Tinggi sebesar 53,75\% dari 80 Siswa. Sedangkan hasil belajar matematika siswa SDN Emmy Saelan Makassar untuk interval nilai 7-7,4 dengan rata-rata sebesar $62,5 \%$. Hasil analisis statistik nonprametrik dimana nilai koefisien korelasi evaluasi dengan motivasi versi Kendall adalah sebesar 0,522, sedangkan nilai koefisien korelasi menurut Spearman adalah sebesar 0,575. Dari perhitungan nilai t hitung, dimana $\mathrm{H}_{0}$ adalah tidak ada pengaruh antara kedua variabel dan $\mathrm{H}_{1}$ adalah ada pengaruh antara kedua variable, $\mathrm{t}$ hitung $>\mathrm{t}$ tabel maka $\mathrm{H}_{0}$ ditolak. Nilai t hitung (5,405 untuk Kendall dan 6,208 untuk Sperman > t tabel 2,326 maka $\mathrm{H}_{0}$ ditolak dan $\mathrm{H}_{1}$ diterima. Jadi Terdapat hubungan antara motivasi belajar terhadap hasil belajar siswa SDN Emmy Saelan Makassar.
\end{abstract}

Kata Kunci: Hubungan Motivasi Belajar, Hasil belajar.

\begin{abstract}
The purpose of this study is to find out about the motivation in learning mathematics influencing students' learning outcomes at Emmy Saelan Elementary School of Makassar. This research is an experimental study with the type of Quasi Experimental research with the research design used in this study is the desaign Non Equivalent Control Group. The sampling technique used is random sampling. The research instruments used in data collection were questionnaires and documentation. The data analysis technique used was descriptive analysis and nonparametric statistical analysis. The results of the descriptive analysis for student motivation in the High category amounted to 53.75\% of 80 Students. While the mathematics learning outcomes of students at the Emmy Saelan Elementary School in Makassar for intervals of grades 7-7.4 with an average of 62.5\%. The results of nonprametric statistical analysis in which the evaluation correlation coefficient with the motivation of the Kendall version is $s$ of 0.522 , whereas the Spearman correlation coefficient value is 0.575 . From the calculation of the value of $t$ count, where $H_{0}$ is no influence between the two variables and $H_{1}$ is there is an influence between the two variables, $t$ count $>t$ table then $H_{0}$ is rejected. The value of $t$ count (5.405 for Kendall and 6.208 for Sperman > t table 2.326 then $H_{0}$ is rejected and $H_{1}$ is accepted. To sum up, there is a relationship between learning motivation towards the students' learning outcomes at Emmy Saelan Elementary School of Makassar.
\end{abstract}

Keywords: Relationships Motivation Learning, Learning Outcomes Mathematics 


\section{Pendahuluan}

Salah satu bidang yang berkembang di era pembangunan dewasa ini, khususnya di Indonesia adalah pada bidang pendidikan. Pendidikan adalah salah satu kebutuhan dasar manusia, karena pada dasarnya pendidikan merupakan suatu proses untuk membantu manusia dalam mengembangkan dirinya sehingga mampu untuk menghadapi setiap perubahan yang terjadi (Pinayu, 2015:182). Pendidikan merupakan salah satu aspek yang memiliki peranan penting dalam peningkatan kualitas sumber daya manusia. Perbaikan kegiatan belajar mengajar harus diupayakan secara optimal agar mutu pendidikan dapat meningkat.

Lembaga pendidikan terutama sekolah berusaha mengarahkan dan memaksimalkan efektivitas belajar dengan jalan merencanakan dan mengorganisasikan pengalaman belajar mengajar. Usaha itu secara sederhana sering dipandang dan diperlakukan sebagai suatu sistem "Input-Proses-Produk". Input antara lain terdiri dari siswa dengan potensi dan karakteristiknya, guru dengan kemampuan dan pengalamannya, tujuan, materi, media, sumber, serta fasilitas yang siap diolah/diproses dalam pengalaman belajar mengajar. Dalam pengalaman belajar mengajar terjadi interaksi yang terarah, terkendali, dan terintegrasi antar bagian dari input, dengan harapan terjadinya perubahan/perkembangan dan itulah yang dimaksud sebagai produk (hasil keluarannya).

Pada tingkat formal, pendidikan diselenggarakan di sekolah-sekolah. Penyelenggaraan pendidikan di sekolah-sekolah itulah yang seringkali lebih dikenal dengan nama pembelajaran, dimana terjadi proses belajar mengajar yang melibatkan banyak faktor baik pengajar, pelajar, bahan atau materi, fasilitas maupun lingkungan. Pembelajaran dilaksanakan tidak hanya untuk kesenangan atau bersifat mekanis saja, akan tetapi mempunyai misi atau tujuan tertentu yang dicita-citakan untuk dicapai kelak. Dalam usaha untuk mencapai misi atau tujuan tersebut, semua kegiatan, fasilitas atau dana, dan daya diorientasikan untuk pencapaian misi atau tujuan yang dicitacitakan tersebut.

Kurikulum sekolah sekarang ini menggunakan pendekatan yang berorientasi kepada pencapaian tujuan sehingga tercapainya tujuan merupakan hal yang penting. Oleh karena itu, situasi belajar mengajar dipandang dan diperlakukan karena belajar adalah suatu proses yang dilakukan seseorang untuk memperoleh suatu perubahan tingkah laku yang baru secara keseluruhan, sebagai hasil pengalamannya sendiri dalam interaksi dengan lingkungannya (Haling, 2006:1). Siswa adalah penentu terjadinya proses belajar di sekolah. Proses belajar terjadi karena adanya siswa yang memperoleh sesuatu yang ada di lingkungan sekitar (Dimyati \& Mudjiono, 2002:5). Pada dasarnya siswa berbeda antara yang satu dengan yang lainnya, baik dalam hal kemampuan maupun cara belajar. Bahkan dapat dikatakan bahwa siswa berbeda seperti sidik jari. Ini berarti setiap siswa mempunyai ciri khas dan kebutuhan yang berbeda-beda antara satu dengan yang lainnya, sebagaimana berbedanya sidik jari setiap orang. Akan tetapi, dalam hal pembelajaran yang berlangsung secara klasikal, perbedaan individu jarang sekali mendapat perhatian.

Menurut Slameto (1995:28) hakekat belajar adalah (1) belajar adalah proses kontinyu, maka harus tahap demi tahap menurut perkembangannya (2) belajar adalah proses organisasi adaptasi, eksplorasi dan penemuan (3) belajar adalah proses kontinuitas (hubungan antara pengertian yang satu dengan yang lain) sehingga 
mendapatkan pengertian yang diharapkan. Sedangkan Sudjana (2004:22), mengemukakan pengertian lain dari hasil belajar merupakan kemampuan-kemampuan yang dimiliki seseorang setelah ia mengalami pengalaman belajarnya. Perkembangan terhadap pembelajaran membawa konsekuensi kepada guru untuk meningkatkan peranannya. Oleh karena itu, dalam meningkatkan hasil belajar maka perlu diadakan suatu evaluasi.

Dalam kegitan belajar mengajar, apabila ada seorang siswa tidak berbuat sesuatu yang seharusnya dikerjakan, maka perlu diselidiki sebabnya. Sebab itu biasanya bermacam-macam, mungkin tidak senang, sakit, lapar, ada problem pribadi, dan lainlain. Hal ini berarti pada diri anak tidak terjadi perubahan energi, tidak terangsang afeksinya untuk melakukan sesuatu karena tidak memiliki tujuan atau kebutuhan belajar. Keadaan semacam ini, perlu dilakukan daya upaya yang dapat menemukan sebab-sebabnya dan kemudian mendorong siswa itu mau melakukan pekerjaan yang seharusnya dilakukan, yakni belajar. Dengan kata lain, siswa itu perlu diberikan rangsangan agar tumbuh motivasi pada dirinya.

Menurut Hading (2006:98), motivasi di pandang sebagai dorongan mental yang menggerakkan dan mengarahkan perilaku manusia, termasuk perilaku belajar. Memberikan motivasi kepada seorang siswa berarti menggerakkan siswa untuk melakukan sesuatu atau ingin melakukan sesuatu. Beberapa cara untuk menimbulkan motivasi adalah melalui cara belajar yang bervariasi, mengadakan suatu pengulangan informasi, memberi stimulus baru, dan melakukan evaluasi belajar. Proses belajar mengajar sangat berkaitan dengan evaluasi agar kemampuan dan kelakuan yang diharapkan dapat dikuasai siswa secara langsung setelah selesainya setiap interaksi belajar mengajar, yang memang memerlukan perulangan dan evaluasi untuk dapat menguasainya.

Penelitian yang terkait dengan hubungan antara motivasi dan hasil belajar juga telah dilakukan oleh Jufri. A (2014), I Gede J (2010), Eliga. F (2013), Toyo. P (2015), Willibaldus, B (2015), Intang Sapalle. B (2007), dan Aritongan. K.T (2008) menunjukkan bahwa motivasi belajar merupakan salah satu faktor pendukung untuk meningkatkan hasil belajar siswa. Oleh karena itu, maka peneliti ingin meneliti tentang hubungan antara motivasi belajar terhadap hasil belajar matematika siswa SDN Emmy Saelan Makassar.

\section{Metode Penelitian}

Penelitian ini menggunakan pendekatan kuantitatif. Penelitian ini dilakukan di SDN Emmy Saelan Makassar, Jalan Tamalate VI Kecamatan Rappocini Kelurahan Mappala Makassar. Populasi dalam penelitian ini adalah siswa SDN Emmy Saelan Makassar dengan jumlah siswa sebesar 320 orang. Teknik yang digunakan dalam pengambilan sampel yaitu dengan menggunakan simple random sampling. simple random sampling adalah cara pengambilan sampel dengan semua objek atau elemen populasi memiliki kesempatan yang sama untuk dipilih sebagai sampel, jumlah sampel penelitian adalah $25 \%$ dari populasi yaitu 80 orang siswa. Teknik pengumpulan data yang digunakan adalah tes dan observasi. Instrumen dalam penelitian kuantitatif dapat berupa test, pedoman wawancara, pedoman observasi, dan kuesioner. Teknik analisis data dalam penelitian ini adalah dengan analisis korelasi bivariat (Spearman dan Kendall), untuk mengetahui hubungan antara hasil belajar dengan motivasi belajar siswa SDN Emmy Saelan Makassar dan untuk mengetahui faktor-faktor apa yang mempengaruh motivasi belajar siswa, dilakukan analisis deskriptif. 


\section{Hasil dan Pembahasan}

\subsection{Hasil Penelitian}

\subsubsection{Motivasi Belajar}

Distribusi motivasi belajar dari sampel yang diteliti pada siswa SDN Emmy Saelan Makassar disajikan pada tabel berikut:

Tabel 1. Distribusi Motivasi Belajar pada Siswa SDN Emmy Saelan Makassar

\begin{tabular}{clccc}
\hline No & Jawaban Siswa & Frekuensi & $\%$ & $\%$ Kumulatif \\
\hline 1. & Selalu & 13 & 16,25 & 16,25 \\
2. & Sering & 43 & 53,75 & 70 \\
3. & Kadang-kadang & 20 & 25 & 95 \\
4. & Tidak Pernah & 4 & 5 & 100 \\
\hline & Total & 80 & 100.00 & - \\
\hline
\end{tabular}

Berdasarkan tabel 1, menunjukkan bahwa jawaban siswa kategori sering yaitu sebesar 53,75\%, jawaban siswa pada kategori selalu yaitu $16,25 \%$, sedangkan pada kategori kadang-kadang yaitu sebesar $25 \%$ serta tidak pernah yaitu $5 \%$. Jadi rata-rata jawaban siswa adalah berada kategori sering untuk setiap pertanyaan yang menyangkut motivasi belajar.

1. Kehadiran sebelum jam pelajaran dimulai

Hasil observasi nomor 1 tentang kehadiran siswa di kelas sebelum jam pelajaran dimulai, selengkapnya disajikan dalam tabel berikut.

Tabel 2. Kehadiran Siswa Sebelum Jam Pelajaran Dimulai

\begin{tabular}{clcc}
\hline No & Jawaban Siswa & Frekuensi & $\%$ \\
\hline 1. & Selalu & 55 & 68,75 \\
2. & Sering & 17 & 21,25 \\
3. & Kadang-kadang & 8 & 10 \\
4. & Tidak Pernah & 0 & 0 \\
\hline \multicolumn{2}{c}{ Total } & 80 & 100.00 \\
\hline
\end{tabular}

Berdasarkan tabel 2, memperlihatkan bahwa jawaban siswa yaitu berada kategori selalu sebesar 68,75\%, jawaban siswa pada kategori sering yaitu sebesar 21,25\% kategori kadang-kadang, yaitu sebesar 10\%, dan jawaban siswa kategori tidak pernah, yaitu $0 \%$. Jadi rata-rata siswa jawaban siswa adalah selalu hadir sebelum jam pelajaran dimulai

2. Tetap tinggal di kelas menyelesaikan tugas

Berdasarkan hasil observasi nomor 2 tentang siswa yang tetap tinggal di kelas menyelesaikan tugas, selengkapnya disajikan dalam tabel berikut. 
Tabel 3. Tetap Tinggal di Kelas Menyelesaikan Tugas

\begin{tabular}{clcc}
\hline No & Jawaban Siswa & Frekuensi & $\%$ \\
\hline 1. & Selalu & 10 & 12,5 \\
2. & Sering & 22 & 27,5 \\
3. & Kadang-kadang & 44 & 55 \\
4. & Tidak Pernah & 4 & 5 \\
\hline \multicolumn{2}{c}{ Total } & 80 & 100.00 \\
\hline
\end{tabular}

Berdasarkan tabel 3, memperlihatkan bahwa jawaban siswa tertinggi adalah berada kategori kadang-kadang, yaitu sebesar 55\%, pada kategori selalu yaitu sebesar $12,5 \%$, sedangkan pada kategori sering, yaitu sebesar $27,5 \%$ dan yang terendah adalah tidak pernah, yaitu 5\%. Jadi rata-rata jawaban siswa adalah siswa kadang-kadang tetap berada di kelas mengerjakan tugas.

3. Sebelum pembelajaran dimulai siswa mengulang kembali pelajaran sebelumnya

Berdasarkan hasil observasi nomor 3, ditunjukkan bahwa sebelum pembelajaran dimulai siswa mengulang kembali pelajaran sebelumnya, selengkapnya disajikan dalam tabel berikut.

Tabel 4.Sebelum Pembelajaran di Mulai Mengulang Kembali Pelajaran Sebelumnya

\begin{tabular}{clcc}
\hline No & Jawaban Siswa & Frekuensi & $\%$ \\
\hline 1. & Selalu & 12 & 15 \\
2. & Sering & 22 & 27,5 \\
3. & Kadang-kadang & 43 & 53,75 \\
4. & Tidak Pernah & 3 & 3,75 \\
\hline \multicolumn{2}{c}{ Total } & 80 & 100.00 \\
\hline
\end{tabular}

Berdasarkan tabel 4, memperlihatkan bahwa jawaban siswa tertinggi adalah berada kategori kadang-kadang, yaitu sebesar 53,75\%, dan pada kategori sering, yaitu sebesar $27,5 \%$ sedangkan pada kategori selalu yaitu sebesar $15 \%$ dan yang terendah adalah tidak pernah, yaitu $3,75 \%$. Jadi rata-rata jawaban siswa adalah siswa kadangkadang sebelum pembelajaran dimulai mengulang kembali pelajaran sebelumnya.

4. Siswa memperhatikan guru yang sedang menulis materi dipapan tulis

Berdasarkan hasil observasi nomor 4 ditunjukkan bahwa siswa yang memperhatikan guru yang sedang menulis materi dipapan tulis, selengkapnya disajikan dalam bentuk tabel berikut.

Tabel 5. Siswa Memperhatikan Guru yang Sedang Menulis Materi di Papan Tulis

\begin{tabular}{clcc}
\hline No & Jawaban Siswa & Frekuensi & $\%$ \\
\hline 1. & Selalu & 39 & 48,75 \\
2. & Sering & 29 & 36,25 \\
3. & Kadang-kadang & 12 & 15 \\
4. & Tidak Pernah & 0 & 0 \\
\hline \multicolumn{2}{c}{ Total } & 80 & 100.00 \\
\hline
\end{tabular}

Berdasarkan tabel 5, memperlihatkan bahwa jawaban siswa tertinggi adalah berada pada kategori selalu, yaitu sebesar $48,75 \%$, dan pada kategori sering, yaitu 
sebesar 36,25\% sedangkan pada kategori kadang-kadang yaitu sebesar $15 \%$ dan yang terendah adalah tidak pernah, yaitu $0 \%$. Jadi rata-rata jawaban siswa adalah siswa selalu memperhatikan guru yang sedang menulis materi dipapan tulis.

5. Siswa selalu merasa segar bugar tanpa mengantuk selama PBM

Berdasarkan hasil observasi nomor 5 ditunjukkan bahwa siswa selalu merasa segar bugar tanpa mengantuk selama PBM, selengkapnya disajikan dalam tabel berikut.

Tabel 6. Siswa Selalu Merasa Segar Bugar Tanpa Mengantuk Selama PBM

\begin{tabular}{clcc}
\hline No & Jawaban Siswa & Frekuensi & $\%$ \\
\hline 1. & Selalu & 6 & 7,5 \\
2. & Sering & 16 & 20 \\
3. & Kadang-kadang & 55 & 68,75 \\
4. & Tidak Pernah & 3 & 3,75 \\
\hline \multicolumn{2}{c}{ Total } & 80 & 100.00 \\
\hline
\end{tabular}

Berdasarkan tabel 6, memperlihatkan bahwa jawaban siswa tertinggi adalah berada kategori kadang-kadang, yaitu sebesar 68,75\%, kategori selalu yaitu 7,5\% sedangkan pada kategori sering yaitu $20 \%$ dan yang kategori tidak pernah, yaitu 3,75\%. Jadi rata-rata jawaban siswa adalah kadang-kadang siswa merasa segar bugar tanpa mengantuk selama PBM berlangsung.

6. Siswa mendiskusikan tugas-tugas belajar dengan teman secara serius

Hasil observasi nomor 6 ditunjukkan bahwa siswa mendiskusikan tugas-tugas belajar dengan teman secara serius, selengkapnya disajikan dalam bentuk tabel berikut.

Tabel 7. Siswa Mendiskusikan Tugas-Tugas Belajar dengan Teman Secara Serius

\begin{tabular}{clcc}
\hline No & Jawaban Siswa & Frekuensi & $\%$ \\
\hline 1. & Selalu & 12 & 15 \\
2. & Sering & 26 & 32,5 \\
3. & Kadang-kadang & 40 & 50 \\
4. & Tidak Pernah & 2 & 2,5 \\
\hline \multicolumn{2}{c}{ Total } & 80 & 100.00 \\
\hline
\end{tabular}

Berdasarkan tabel 7, memperlihatkan bahwa jawaban siswa tertinggi adalah berada kategori kadang-kadang, yaitu sebesar 50\%, dan pada kategori sering yaitu $32,5 \%$ sedangkan pada kategori selalu yaitu $15 \%$ dan yang terendah adalah tidak pernah, yaitu 2,5\%. Jadi rata-rata jawaban siswa adalah siswa kadang-kadang mendiskusikan tugas-tugas belajar dengan teman secara serius untuk menguasai pelajaran.

7. Siswa mendengar dan mencatat semua penjelasan guru yang dianggap penting

Hasil observasi nomor 7 ditunjukkan bahwa siswa mendengar dan mencatat semua penjelasan guru yang dianggap penting secara serius, selengkapnya disajikan dalam bentuk tabel berikut. 
Tabel 8.Siswa Mendengar dan Mencatat Semua Penjelasan Guru yang Dianggap Penting

\begin{tabular}{clcc}
\hline No & Jawaban Siswa & Frekuensi & $\%$ \\
\hline 1. & Selalu & 33 & 41,25 \\
2. & Sering & 32 & 40 \\
3. & Kadang-kadang & 15 & 18,75 \\
4. & Tidak Pernah & 0 & 0 \\
\hline \multicolumn{2}{c}{ Total } & 80 & 100.00 \\
\hline
\end{tabular}

Berdasarkan tabel 8, memperlihatkan bahwa jawaban siswa tertinggi adalah berada kategori selalu, yaitu sebesar $41.25 \%$, dan pada kategori sering yaitu $40 \%$ sedangkan pada kategori kadang-kadang yaitu $18,75 \%$ dan yang terendah adalah tidak pernah, yaitu 0\%. Jadi rata-rata jawaban siswa adalah siswa selalu mendengarkan dan mencatat semua penjelasan guru yang dianggap penting secara serius.

8. Siswa mengikuti PBM sejak awal pelajaran hingga akhir pelajaran

Hasil observasi nomor 8 ditunjukkan bahwa siswa mengikuti PBM sejak awal pelajaran sampai akhir pelajaran, selengkapnya disajikan dalam bentuk tabel berikut.

Tabel 9. Siswa Mengikuti PBM Sejak Awal Pelajaran Hingga Akhir Pelajaran

\begin{tabular}{clcc}
\hline No & Jawaban Siswa & Frekuensi & $\%$ \\
\hline 1. & Selalu & 51 & 63,75 \\
2. & Sering & 16 & 20 \\
3. & Kadang-kadang & 13 & 16,25 \\
4. & Tidak Pernah & 0 & 0 \\
\hline \multicolumn{2}{c}{ Total } & 80 & 100.00 \\
\hline
\end{tabular}

Berdasarkan tabel 9, memperlihatkan bahwa jawaban siswa tertinggi adalah berada kategori selalu, yaitu sebesar $63,75 \%$, dan pada kategori sering yaitu $20 \%$, sedangkan pada kategori kadang-kadang yaitu $16,25 \%$ dan yang terendah adalah tidak pernah, yaitu 0\%. Jadi rata-rata jawaban siswa adalah siswa selalu mengikuti PBM sejak awal pelajaran sampai akhir pelajaran.

9. Siswa tetap terfokus pada pelajaran meskipun ada siswa yang mengganggu

Hasil observasi nomor 9 ditunjukkan bahwa siswa tetap terfokus meskipun ada siswa yang mengganggu, selengkapnya disajikan dalam bentuk tabel berikut.

Tabel 10.Siswa Tetap Terfokus Meskipun Ada Siswa yang Mengganggu

\begin{tabular}{c|l|c|c}
\hline No & Jawaban Siswa & Frekuensi & $\%$ \\
\hline 1. & Selalu & 9 & 11,25 \\
2. & Sering & 16 & 20 \\
3. & Kadang-kadang & 51 & 63,75 \\
4. & Tidak Pernah & 4 & 5 \\
\hline \multicolumn{2}{r|}{ Total } & 80 & 100.00 \\
\hline
\end{tabular}

Berdasarkan tabel 10, memperlihatkan bahwa jawaban siswa tertinggi adalah berada kategori kadang-kadang, yaitu sebesar $63,75 \%$, dan pada kategori selalu yaitu $11,25 \%$ sedangkan pada kategori sering yaitu $20 \%$ dan yang terendah adalah tidak 
pernah, yaitu 5\%. Jadi rata-rata jawaban siswa adalah siswa kadang-kadang tetap terfokus pada pelajaran meskipun ada yang mengganggu.

10. Siswa menyelesaikan tugas belajar di kelas tanpa istirahat sebelum waktu pelajaran berakhir.

Hasil observasi nomor 10 ditunjukkan bahwa siswa menyelesaikan tugas belajar di kelas tanpa istirahat sebelum waktu pelajaran di mulai, selengkapnya disajikan dalam bentuk tabel berikut

Tabel 11. Siswa Menyelesaikan Tugas di Kelas Tanpa Istirahat Sebelum Waktu Pelajaran Berakhir

\begin{tabular}{clcc}
\hline No & Jawaban Siswa & Frekuensi & $\%$ \\
\hline 1. & Selalu & 8 & 10 \\
2. & Sering & 22 & 27,5 \\
3. & Kadang-kadang & 44 & 55 \\
4. & Tidak Pernah & 6 & 7,5 \\
\hline \multicolumn{2}{c}{ Total } & 80 & 100.00 \\
\hline
\end{tabular}

Berdasarkan tabel 11, memperlihatkan bahwa jawaban siswa tertinggi adalah berada kategori sering, yaitu sebesar $27,5 \%$, dan pada kategori kadang-kadang yaitu $55 \%$ sedangkan pada kategori selalu yaitu $10 \%$ dan yang terendah adalah tidak pernah, yaitu $7,5 \%$. Jadi rata-rata jawaban siswa adalah siswa sering tetap menyelesaikan tugas belajar di kelas tanpa istirahat sebelum waktu pelajaran berakhir.

\subsubsection{Hasil Belajar}

Distribusi hasil belajar dari sampel yang diteliti pada Siswa SDN Emmy Saelan Makassar disajikan pada tabel berikut :

\begin{tabular}{ccccc}
\multicolumn{4}{c}{ Tabel 12. Distribusi Evaluasi Belajar pada Siswa SDN Emmy Saelan Makassar } \\
\hline No & Nilai Siswa & Frekuensi & $\%$ & \% Kumulatif \\
\hline 1. & $>8$ & 7 & 8,75 & 8,75 \\
2. & $7,5-8$ & 21 & 26,25 & 35 \\
3. & $7-7,4$ & 50 & 62,5 & 9,75 \\
4. & $<7$ & 2 & 2,5 & 100 \\
\hline & Total & 80 & 100.00 & - \\
\hline
\end{tabular}

Berdasarkan tabel 12, menunjukkan bahwa rentang nilai siswa yang tertinggi adalah 7-7,4 yaitu sebesar $62,5 \%$, sedangkan nilai yang terendah adalah $<7$ yaitu sebesar $2,5 \%$. Jadi rata-rata nilai siswa adalah $7-7,4$ dalam setiap evalusi yang dilaksanakan. 
Data distribusi siswa SDN Emmy Saelan Makassar berdasarkan motivasi belajar dan hasil belajar siswa adalah sebagai berikut :

Tabel 13. Distribusi Siswa Berdasarkan Motivasi Belajar dan Hasil Belajar Siswa SDN Emmy Saelan Makassar

\begin{tabular}{|c|c|c|c|c|c|}
\hline \multirow{2}{*}{ Motivasi } & \multicolumn{4}{|c|}{ Evaluasi } & \multirow{2}{*}{ Total } \\
\hline & $>8$ & $7,5-8$ & $7-7,4$ & $<7$ & \\
\hline Selalu & 2 & 11 & 0 & 0 & 13 \\
\hline Sering & 5 & 8 & 30 & 0 & 43 \\
\hline Kadang-kadang & 0 & 2 & 17 & 1 & 20 \\
\hline Tidak Pernah & 0 & 0 & 3 & 1 & 4 \\
\hline Total & 7 & 21 & 50 & 2 & 80 \\
\hline
\end{tabular}

Berdasarkan tabel 13, menunjukkan bahwa motivasi belajar para siswa untuk kategori selalu dengan frekuensi nilai tertinggi adalah 7,5-8 yaitu sebesar 11 siswa, untuk kategori sering dengan frekuensi nilai tertinggi adalah 7-7,4 yaitu sebesar 30 siswa, untuk kategori kadang-kadang dengan frekuensi nilai tertinggi adalah 7-7,4 yaitu sebesar 17 siswa, dan untuk kategori tidak pernah dengan frekuensi nilai tertinggi adalah 7-7,4 yaitu sebesar 3 siswa.

\subsection{Analisis Hubungan Hasil Belajar terhadap Motivasi Belajar Siswa}

\subsubsection{Uji Bivariat Kendall dan Spearman}

Selanjutnya hasil estimasi yang mempengaruhi hasil belajar dapat dilihat pada tabel berikut :

Tabel 14. Hasil Estimasi Hubungan Motivasi Belajar terhadap Hasil Belajar Siswa SDN Emmy Saelan Makassar

\begin{tabular}{lc}
\hline \multicolumn{1}{c}{ Koefisien Korelasi } & Hasil belajar dan Motivasi \\
\hline Kendall & 0,522 \\
Spearman & 0,575 \\
\hline Level signifikan : 0,01 & \\
\hline
\end{tabular}

Berdasarkan tabel 14, menunjukkan bahwa nilai koefisien korelasi hasil belajar dengan motivasi belajar menggunakan versi Kendall adalah sebesar 0,522, sedangkan menggunakan versi Spearman adalah sebesar 0,575. Dimana $\mathrm{H}_{\mathrm{o}}=$ tidak ada pengaruh antara kedua variabel dan $\mathrm{H}_{1}=$ ada pengaruh antara kedua variable, dimana $\mathrm{t}$ hitung $>\mathrm{t}$ tabel maka $\mathrm{Ho}=$ tidak ada pengaruh antara dua variabel ditolak. $\mathrm{T}$ hitung $(5,405$ untuk versi Kendall dan 6,208 untuk versi Spearman) > t tabel $(78 ; 0,01)$ 2,326, maka $\mathrm{H}_{\mathrm{o}}=$ tidak ada pengaruh antara dua variabel ditolak dan $\mathrm{H}_{1}=$ ada pengaruh antara dua variabel diterima. Jadi dapat disimpulkan bahwa ada pengaruh antara kedua variabel. 


\subsubsection{Analisis Frekuensi}

Hasil estimasi analisis frekuensi motivasi belajar terhadap hasil belajar Siswa SDN Emmy Saelan Makassar dapat dilihat pada tabel berikut :

Tabel 15. Hasil Estimasi Hubungan Motivasi Belajar Terhadap Hasil Belajar Siswa SDN Emmy Saelan Makassar

\begin{tabular}{lcc}
\hline & Hasil Belajar & Motivasi \\
\hline $\mathrm{N}$ & 80 & 80 \\
Mean & 2,59 & 2,19 \\
Median & 3.00 & 2.00 \\
Mode & 3 & 2 \\
Standar Deviasi & 0,688 & 0,765 \\
Varians & 0,473 & 0,585 \\
\hline
\end{tabular}

Berdasarkan tabel 15, menunjukkan bahwa $\mathrm{N}$ merupakan jumlah data pengamatan sebesar 80 untuk hasil belajar dan motivasi belajar. Mean merupakan ratarata hitung dari data yang diteliti dimana untuk hasil belajar sebesar 2,59 dan untuk motivasi belajar sebesar 2,19. Median merupakan nilai tengah data yang diteliti dimana untuk hasil belajar sebesar 3,00 dan untuk motivasi belajar sebesar 2,00. Mode merupakan nilai yang sering muncul dari data yang diteliti dimana untuk hasil belajar sebesar 3 dan untuk motivasi belajar sebesar 2. Standar deviasi data yang diteliti untuk hasil belajar sebesar 0,688 dan untuk motivasi belajar sebesar 0,765.

\subsection{Pembahasan}

Motivasi belajar sangat mempengaruhi dalam kegiatan belajar siswa dimana motivasi merupakan keseluruhan daya penggerak di dalam diri siswa yang menimbulkan kegiatan belajar, yang menjamin kelangsungan dari kegiatan belajar dan yang memberikan arah pada kegiatan belajar sehingga tujuan yang dikehendaki dapat tercapai. Hasil belajar adalah hasil yang diperoleh dan dimiliki setelah melibatkan dirinya secara aktif, baik dari segi fisik maupun mental dalam menyelesaikan masalah. Evaluasi pembelajaran merupakan alat untuk menentukan apakah tujuan pendidikan dan apakah proses dalam pengembangan ilmu pengetahuan telah berada dijalan yang diharapkan.

Motivasi belajar siswa mempunyai hubungan yang erat dengan hasil belajar siswa yang dilakukan dalam proses belajar mengajar siswa di sekolah. Kategori siswa yang memilih jawaban selalu untuk pertanyaan yang berhubungan dengan motivasi belajar, belum tentu memiliki hasil belajar yang tinggi. Namun kategori siswa yang memilih sering merupakan jawaban terbesar dari pertanyaan yang berhubungan dengan motivasi belajar siswa.

Nilai koefisien korelasi hasil belajar dengan motivasi versi Kendall adalah sebesar 0,522, sedangkan menurut Spearman adalah sebesar 0,575. Data tersebut menggambarkan bahwa ada pengaruh antara motivasi belajar terhadap hasil belajar siswa SDN Emmy Saelan Makassar.

Data hubungan hasil belajar dengan motivasi belajar siswa menggambarkan bahwa dari 80 sampel yang diteliti, nilai $3(7-7,4)$ untuk hasil belajar dan nilai 2 (sering) untuk motivasi belajar. Dari kedua data tersebut menggambarkan bahwa siswa 
yang menjawab pertanyaan yang berhubungan dengan motivasi dengan jawaban sering kebanyakan mendapatkan hasil belajar 7-7,4.

\section{Kesimpulan}

Berdasarkan hasil dan pembahasan penelitian, berikut ini peneliti akan mengambil beberapa kesimpulan yaitu karakteristik siswa dalam menjawab pertanyaan yang menyangkut motivasi belajar yang tertinggi adalah sering yaitu sebesar 53,75\%, dan jawaban siswa yang terendah adalah tidak pernah yaitu sebesar 5\%. Jadi rata-rata kategori jawaban siswa adalah sering untuk setiap pertanyaan yang menyangkut motivasi belajar siswa. Karakteristik siswa yang menyangkut hasil belajar dengan rentang nilai tertinggi adalah 7-7,4 yaitu sebesar $62,5 \%$, sedangkan nilai terendah adalah $<7$ yaitu sebesar 2,5\%. Jadi rata-rata nilai siswa adalah 7-7,4 pada hasil belajar siswa. Motivasi belajar berpengaruh terhadap hasil belajar siswa SDN Emmy Saelan Makassar, dimana ada hubungan antara kedua variabel.

\section{Daftar Pustaka}

Arikunto, S. \& Safruddin, C. (2004). Evaluasi Program Pendidikan. Pedoman Teoritis Praktis bagi Praktisi Pendidikan. Cetakan I, Penerbit Bumi Aksara, Jakarta.

Aritonang, K., T. (2008). Minat dan Motivasi dalam meningkatkan Hasil Belajar, Jakarta

Dimyati \& Mudjiono. (2002). Belajar dan Pembelajaran. Penerbit Rineka Cipta. Jakarta.

Eliya, F (2013). Hubungan antara Kesiapan belajar dengan Hasil Belajar matematika Warga Belajar Kelas XI Klp Belajar Paket C SKB Bondowoso Semester genap, Universitas Jember.

Hading, A.(2006). Belajar dan Pembelajaran. Badan Penerbit UNM. Makassar

I Gede J (2010). Hubungan Disiplin Belajar dan Motivasi Berprestasi dengan Hasil Belajar Teknologi Informasi dan Komunikasi Siswa Kelas VII Tahun 2009/2010 SMP Negeri 5 Abang Karang Asam Singaraja, Universitas Pendidikan Ganesha.

Intang, S., B. (2007). Hubungan Kemampuan Penalaran dalam Matematika dan Motivasi Berprestasi terhadap Prestasi Belajar Matematika.

Jufri, A. (2014). Hubungan Motivasi Belajar dengan Hasil Belajar Matematika Siswa kelas IV SDN 1451 Tebing Tinggi Jambi. FKIP Universitas Jambi.

Sudjana. (2004). Dasar-Dasar Proses Belajar Mengajar. PT. Sinar Baru Algesindo, Bandung. 
Toyo, P. (2015). Hubungan antara Motivasi Berprestasi dengan Hasil Belajar Matematika pada Kelas IV SD Segugus V Kecamatan Mauponggo Kabupaten Nagekeo Tahun 2015/2016 Bajawa. STKIP Citra Bakti.

Willibaldus, B. (2015). Hubungan antara Motivasi dengan Hasil Belajar Matematika pada Siswa SMP Program Studi matematika, STKIP Citra Bakti NTT.

Slameto. (2003). Belajar dan Faktor-Faktor yang Mempengaruhinya. Cetakan IV, Rineka Cipta, Jakarta. 